\title{
An investigation of the citation transformation types in M.A. and PhD theses
}

\author{
Fatma Şeyma Doğan ${ }^{1 *}$, Oktay Yağız² and Işıl Günseli Kaçar ${ }^{3}$
}

\author{
* Correspondence: \\ fsdogan@harran.edu.tr \\ ${ }^{1}$ Harran University, Şanlıurfa, Turkey \\ Full list of author information is \\ available at the end of the article
}

\begin{abstract}
This study investigates the types of citation transformation preferred by both English L1 (native language) writers and Turkish writers who use English as a foreign language (L2). The corpus consists of 34 theses, 17 of which are Turkish writers' theses in English language including 10 M.A. and 7 PhD theses and 17 English L1 writers' theses comprised of 10 M.A. and 7 PhD theses. Based on the relevant literature, a rubric was prepared by the researchers in order to analyse the theses by means of qualitative content analysis. The findings revealed that three forms of content integration consisting of direct quotation, patchwriting and critical evaluation were markedly different in English L1 and Turkish writers' theses. Turkish L1 writers' overuse of direct quotation and patchwriting attracted attention compared to English L1 writers.
\end{abstract}

Keywords: Citation, Knowledge transformation, English academic writing

\section{Introduction}

Using other researchers' views, arguments and research findings in another scientific text is a prominent feature, and meanwhile, a necessity in scholarly writing to justify arguments and claims. Citation hereby assists the writer to demonstrate what is different from previous arguments, and in what way the gap is to be filled emphasizing the new ideas and arguments. Nevertheless, the formal statement of others' views requires achieving certain conventions and norms, which can otherwise cause ethical and legal constraints and accusations such as plagiarism, patch-writing or inappropriate text. Therefore, aspects of citation practices and the skill of use of appropriate acknowledgement of others' ideas and findings have a close relationship with academic integrity.

Academic integrity refers to "the avoidance of intentional, unintentional and self-plagiarism via correct citation and referencing practices" (Marsh and Campion 2018, p.214). It is increasingly acknowledged that as the concept of academic integrity is grounded on cultural considerations (Al-Shamaa et al. 2017), it is not easily understood by international students. In other words, students' assumptions of acknowledgement are shaped by their cultural interpretations of academic textmaking, as pointed out in East (2009). Also, there may be a lack of congruence between students' understanding of acknowledgement and those who are their

(c) The Author(s). 2018 Open Access This article is distributed under the terms of the Creative Commons Attribution 4.0 International License (http://creativecommons.org/licenses/by/4.0/), which permits unrestricted use, distribution, and reproduction in any medium, provided you give appropriate credit to the original author(s) and the source, provide a link to the Creative Commons license, and indicate if changes were made. 
assessors (Emerson 2008). Furthermore, it may be possible that students may be confused in the face of different available citation styles in accordance with different academic disciplines (East and Donnelly 2012).

Citation is considered one of the important types of writing, which is natural, inevitable and required and citation practices are regarded as an integral part of academic writing (Hyland 1999). Although writing an academic text cannot be divorced from understanding and integrating others' work into one's own studies, how to accurately and appropriately use others' sources is still challenging and demanding for novice writers. In order to be recognized as a member of a professional academic writing community, it is crucial for novice writers, particularly non-native speakers of English (NNS) need to be informed of various citation practices in their academic disciplines as well as what, how, when and why to cite relevant studies when needed (Swales 1986). Unacknowledged replication may be viewed as a legitimate and respectful practice in some students' prior educational backgrounds (Angelil-Carter 2000; Burns 1991; Handa and Power 2005). In order to promote the development of academic integrity in tertiary settings, a need has arisen to address the concerns about the lack of familiarity with citation practices (East \& Donnelly, 2012; Marsh and Campion 2018).

In order to raise students' awareness of academic integrity by teaching them the academic conventions of acknowledgement and citation styles in accordance with their academic disciplines, it is necessary to reveal the differences between citation practices employed by writers with English as L1 (native speakers of English) and those with English as L2 (non-native speakers of English). Comparative studies provide in-depth knowledge regarding L1 and L2 academic texts (Hinkel 2002).

Many researchers claim that control and appropriate implementation of citation in academic texts are a late-developing phenomenon not only for native but also for non-native writers of English (Borg 2000; Mohan and Lo 1985; Pennycook 1996) since learning how to cite is a skill development process that is incremental and time-consuming. Borg (2000) claimed that not only native students but also non-native students experience difficulties in using sources appropriately and taking a stance in their own writing as well because especially non-native speakers of English (NNS) need to learn what to cite, when to cite and why to cite relevant studies, as Swales (1986) claims.

Citation skills constitute one of the important components contributing to academic integrity (Marsh and Campion 2018). Considering the impact of language proficiency and the cultural background of the writers on the types of citation practices they employed from the perspective of academic integrity, a cross-linguistic investigation of these practices is of significance. Hence, one of the aims of this study is to highlight the citation practices employed by English L1 writers and Turkish writers. The findings will shed light into citation practices of not only English L1 writers but also Turkish writers. Thus, they will fill a research gap related to this field particularly, as there seem to be no cross-linguistic studies focusing on the types of citation transformation in graduate theses in the Turkish academic context. However, the insights gained through this study are likely to be beneficial in the international context as well, particularly in the similar EFL academic writing contexts. The insights gained from this case study are likely to be informative for the international audience in terms of how to develop academic 
integrity -related skills, particularly citation practices, and values in the tertiary academic writing contexts. While the focus is on English NS compared to Turkish writers, the findings are likely to assist other writers from other language/cultural backgrounds in establishing a better understanding of the concept of academic integrity and the development of skills integral to the development of this understanding including citation practices.

Uncovering English L1 writers and Turkish writers' citation practices in the M.A. and $\mathrm{PhD}$ theses related to ELT constitutes the other aim in the study. Although all post-graduate students not necessarily follow the same trajectory in their academic career by pursuing an M.A. followed by a PhD Degree, in general there are likely to be differences in the knowledge claim construction and the academic discourse employed, and the degree of sophistication in the employment of citations in the M.A. and $\mathrm{PhD}$ theses. In general, a rise in the degree of sophistication is expected from the M.A. to the $\mathrm{PhD}$ level, but it would be wrong to directly attribute the varying degrees of sophistication in the citation use to developmental factors. Being informed of the differences and similarities regarding citation practices in both are likely to provide a road map and valuable insights for English as an Academic English (EAP) course developers, instructors and materials developers so that they can modify the existing academic writing materials and in-class instruction in line with the learning needs of post-graduate students in terms of citation skills development by laying due emphasis on the appropriate source use, and citation patterns in ELT-related research. They are also likely to be useful for the aforementioned audience in addressing the concerns arising from the lack of familarity with discipline-specific academic writing conventions and citation styles in order to enhance the post-graduate students' level of academic integrity, which, in return, will lead to the development academic integrity among novice scholars in the Turkish tertiary academic context. The investigation of citation practices of relatively novice writers in different stages of their post-graduate studies is of great importance in order to examine the existing patterns in the academic written works of post-graduate students in English Language Teaching (ELT) and English language learning, future academics, in their employment of citation practices, an essential component of academic integrity-related skill.

This corpus-based exploratory study aims to address the following research questions:

Do English L1 and Turkish writers' citation practces differ in English in terms of knowledge transformation?

Do the citation practices differ in M.A. theses and $\mathrm{PhD}$ theses in terms of knowledge transformation?

\section{Review of literature}

Citations practices have been examined from diverse perspectives. Through an applied linguistic lens, for example, citation practices have been studied from three research traditions: discourse analysis, English for research purposes and genre analysis. The starting point of citation practices in applied linguistics goes back to Swales' study 
(1986) on the textual analysis of citation. From this date forward, research studies carried out on citation practices have focused on different dimensions of citation: citation types grounded in linguistic criteria and syntactic position (Swales 1990), the density of citation practices (Coffin 2009; Hyland 1999, 2002; Schembri 2009), the linguistic environment of citations consisting of reporting verbs (Hyland 2002), the reporting structure (Jalilifar \& Dabbi, 2013), and tense (Davidse and Vandelanotte 2011). Moreover, other research studies have examined citation types based on Swales' (1986) categorization of citation types (Coffin 2009; Hyland 1999, 2000; Kafes 2017; Thompson 2005), the rhetorical function of citations (Harwood 2009; Lee et al. 2018; Petric 2007), the writers' citation motivation (Petric 2007), and the nature of cited sources (Coffin 2009).

Research comparing citation practices in the texts written by native and non-native speakers of English (Borg 2000) have been also conducted. Borg (2000) investigated the citation practices of sixteen students enrolled in TESOL programme in the UK. He emphasized the problems of NNS of English in terms of source integration and found that when NNS of English failed to cite appropriately, they could be blamed for breaching academic integrity.

The recent research on citation patterns indicated that citation use also shows variation across academic disciplines (Harwood 2009; Hyland 1999; Mansourizadeh and Ahmad 2011; Petric 2007). To illustrate, softer disciplines, social sciences, tend to utilize more citations in the construction of their texts and the use of integral citations were more common (Hyland 1999). Conversely, in hard sciences writers have a tendency to use more non-integrated citations (Hyland 1999). Harwood (2009), in an interview study on citation functions used by sociologists and computer scientists, found that the former utilized citations for the reader engagement whereas the latter utilized them for signposting. Mansourizadeh and Ahmad (2011), in a case study, explored citation practices in research articles by non-native writers and native experts in chemical engineering with the same language background, novice writers were found to use citations less than expert ones. Novices employed citations less than experienced ones and preferred the citation function attribution, which is used to demonstrate the writers' familiarity with the domain, while the latter used more complex citation functions such as support and establishing links between the sources. Finally, Petric (2007), in a study on the rhetorical citation functions in low-rated and high-rated M.A. theses in gender studies, revealed that both types of theses used citatons but they were used for the knowledge display.

Few attempts have been made to describe the source use of Turkish writers in English. One of the recent corpus-based exploratory studies was carried out by Kafes (2017) into the citation patterns of the Turkish novice academic writers and native English speaking experienced American academic writers in a corpus of 80 empirical research articles from the field of Applied Linguistics, considering certain parameters such as genre, subject matter and reputation. The findings revealed significant similarities and differences in the frequency, type and function of citation practices, with differences outweighing the similarities. Another recent study was conducted by Yağız et al. (2014). They investigated Turkish speakers of English scholars' "literature review" parts of 100 research articles in the field of ELT and Applied Linguistics by means of making use of a rubric prepared by the researchers. These research articles were analysed by content analysis, based on the rubric which included three sections: "the types of content", "the location of source", and 
"the type of transformation". Yağız et al. (2014) claimed that even though the writings of Turkish scholars reflected ELT writing conventions and norms, their writings lacked critical evaluation and sometimes they resorted to patchwriting, which could be the result of inadequate academic literacy awareness. Furthermore, on a micro level study on the generic structure of Turkish and English abstracts in educational abstracts, Candarlı (2012) indicated the Turkish writers' abstinence from the establishment of a niche through the criticism of others' work. Işık-Taş (2008) carried out a contrastive analysis of genre-specific citation practices of Turkish writers. In this study, 25 "introduction" sections of research articles and 25 "introduction" sections of $\mathrm{PhD}$ theses in the field of ELT were analysed by means of content analysis. However, neither study provides a comparative cross-linguistic analysis of Turkish writers' citation practices in M.A. and $\mathrm{PhD}$ theses, which highlights the gap related to citation practices in academic writing in Turkey that have a crucial role in the acknowledgement of the intellectual property and and taking a stance in their own writing.

\section{Methodology}

The corpus of the study comprising two parallel sub-corpora included 34 theses on ELT or English language learning consisting of 17 English L1 writers' theses (10 M.A. theses and $7 \mathrm{PhD}$ theses) and 17 Turkish writers' theses (10 M.A. theses and $7 \mathrm{PhD}$ theses) written between the years 2010 and 2014. The data collection procedure involved two phases: the selection process of M.A. and $\mathrm{PhD}$ theses conducted by NS of English in regard to English language teaching and learning, the selection process of M.A. and PhD theses conducted by Turkish speakers of English with respect to English language teaching and learning. Prior to the conduct of the study, a pilot study was carried out with 5 English L1 writers' and 5 Turkish writers' M.A. and PhD theses on ELT or English language learning.

Seven $\mathrm{PhD}$ theses conducted by NSs of English were randomly selected from a pool of theses associated with the keywords 'English language teaching', and 'English language learning', using two different databases "ProQuest Dissertation and Theses" database, and "EThOS" (Electronic Theses Online Service), the UK's national thesis service, which has access to only $\mathrm{PhD}$ theses conducted in the UK. The selection of the theses analysed in the corpus among the theses available in the pool was based on two criteria including the writers' first and family names, and the university from which the B.A. or M.A. was obtained. However, these criteria were inadequate to be sure about the origins of the writers of the theses. In order to be sure about the origin of the thesis writers, a verification e-mail was sent to the writers of theses whose contact addresses were written on their theses or found by means of the website of the universities they work. Among the theses whose writers sent an answer to our e-mails, $7 \mathrm{PhD}$ theses were randomly chosen. These PhD theses were written between 2010 and 2014, at seven universities around the world.

The corpus of $\mathrm{PhD}$ theses conducted by Turkish writers comprises 7 theses written at the department of English Language Teaching (ELT) at universities located in the seven regions of Turkey written between 2010 and 2014. The theses were randomly downloaded from the official website of the Council of Higher Education (YÖK). The corpus of M.A. theses written on ELT or English language learning 
consists of two parallel subcorpora: 10 theses carried out by English L1 and 10 theses carried out by Turkish writers. M.A. theses written by Turkish writers were randomly selected from open access theses conducted at the department of English language teaching (ELT) via the thesis database of Council of Higher Education (YÖK) while 10 M.A. theses written by English L1 writers on ELT or English language learning were randomly selected among the accessible ones from the international theses database (ProQuest Dissertation and Theses). The same procedure was followed as in the process of selection of $\mathrm{PhD}$ theses written by English L1 writers.

The research design of the corpus was grounded in a modified version of Hyland's (2000) and Yağız et al.'s (2014) typologies. Qualitative content analysis was carried out through a rubric prepared by the researchers (See Additional file 1: Appendix A). The type of transformations was examined in terms of direct quotation, patchwriting, paraphrase, summary and critical evaluation. The direct quotation is the way of transferring information into your text without making any modifications (Petric 2012). Patchwriting can be defined as "copying from a source text and then deleting some words, altering grammatical structures, or plugging in one-for-one synonym substitutes" by Howard (1993, p.233). Paraphrase is defined as "using different phrasing and wording to express a particular passage that was originally written or spoken by someone else in order to blend the other's idea smoothly into one's own writing" (Campbell 1998, p. 86). A recent definition is given by Howard et al., (2010, p. 181) who explain summary as "restating and compressing the main points of a paragraph or more of text in fresh language and reducing summarized passage by at least 50\%". Critical evaluation can be defined as "the conveying of the writer's view of the status of the information in his/her text" (Thompson and Ye 1991, p. 368) and adding his/her voice to the text. I-Thenticate and Turnitin software programmes were utilized to fill the rubric. The data with these codes were recorded in an excel file. Then, the quantitative data were descriptively analysed. To provide inter-rater reliability, two raters who had a background in citation practices independently coded and analysed the citations employed in each thesis in the pilot study simultaneously with the researcher. There was over $90 \%$ agreement between the categorizations of citations among three researchers. The same procedure was followed for 34 theses in the corpus.

\section{Results}

Table 1 below indicates the quantitative findings of English L1 and Turkish writers incorporate content from sources in their theses.

As shown in Table 1, both groups of the writers tended to integrate others' work into their theses by means of summarizing mostly. However, English L1 writers (41.6\%) preferred summary more than Turkish writers (29.9\%). Although both English L1 writers and Turkish writers found incorporating source content as a favourable type of transformation, the former preferred this strategy slightly more than the lattter. Theses produced by English L1 writers displayed a much higher percentage of critical evaluation $(16.6 \%)$ and a lower percentage of direct quotation $(8.7 \%)$ and patchwriting $(0.3 \%)$. Nonetheless, critical evaluation was the least preferred way of transformation for Turkish writers, followed by paraphrase and patchwriting respectively. In fact, the 
Table 1 The Distribution of Citations in English L1 and Turkish Writers' Analysed Theses in regard to the Type of Transformations

\begin{tabular}{|c|c|c|c|c|c|c|}
\hline \multicolumn{4}{|l|}{ English L1 Writers' Theses } & \multicolumn{3}{|c|}{ Turkish Writers' Theses } \\
\hline Type of Transformations & $\mathrm{F}$ & $\%$ & The order of preference ${ }^{a}$ & $\bar{F}$ & $\%$ & The order of preference ${ }^{a}$ \\
\hline Direct Quotation & 378 & 8.7 & 4 & 1048 & 21.8 & 3 \\
\hline Patchwriting & 15 & 0.3 & 5 & 675 & 14.1 & 4 \\
\hline Paraphrase & 1322 & 30.03 & 2 & 224 & 25.5 & 2 \\
\hline Summary & 1812 & 41.6 & 1 & 1438 & 29.9 & 1 \\
\hline Critical Evaluation & 723 & 16.6 & 3 & 139 & 2.9 & 5 \\
\hline Total & 4250 & 97.5 & & 4525 & 94.2 & \\
\hline Incorrect Citation Use & 109 & 2.5 & & 277 & 5.8 & \\
\hline Total & 4359 & & & 4802 & & \\
\hline
\end{tabular}

${ }^{a} \mathrm{f}=$ Frequency, $\%=$ Percentage

${ }^{\mathrm{a}}(1=$ most preferred...5 = least preferred $)$

employment of direct quotation, patchwriting and critical evaluation was markedly different in English L1 and Turkish writers' theses. Given the data in Table 2, $\mathrm{X}^{2}=$ 1443.72, $\mathrm{df}=5$, and $\mathrm{P}\left(\mathrm{X}^{2}>1443.721\right)=0.00$, a chi-square test of independence shows that there is a statistically significant difference between English and Turkish thesis writers.

As shown in Table 3, the source content was integrated as a way of summary (30.2\% in M.A. theses and 39.1\% in PhD theses) and paraphrase $28.4 \%$ in M.A.theses and $27.4 \%$ in $\mathrm{PhD}$ theses) mostly in both M.A. and $\mathrm{PhD}$ theses. However, the writers of $\mathrm{PhD}$ theses made use of summary (39.1\%) more than those of M.A. theses (30.2\%). Direct quotation was the third most preferred way of transformation in two sets of theses but M.A. theses showed a much higher percentage of direct quotation (19\%). There was a decline in the use of direct quotation in $\mathrm{PhD}$ theses (13.2\%). While patchwriting was not found to be a preferred type of transformation in both M.A. and PhD theses, a sharp decline was observed in the use of patchwriting in the $\mathrm{PhD}$ theses. As for the critical evaluation, it was the least preferable type of transformation in not only in M.A theses (7.1\%) but also in $\mathrm{PhD}$ theses (11\%) although a slight increase was observed in the $\mathrm{PhD}$ theses as compared to M.A. theses. Given the data in Table $4, X^{2}=201.591, d f=5$, and $P\left(X^{2}>201.591\right)=$ 0.00 , a chi-square test of independence shows that there is a statistically significant difference between master and doctoral theses' writers.

\section{Discussion}

Given the way the cited material is incorporated into the text, summary and paraphrase were mostly used as a way of transformation of the source content in the theses written by English L1 and Turkish writers. However, English L1 writers made use of summary and paraphrase more than Turkish writers in their theses.

Even though there were no significant differences between these two types of source content transformation in English L1 and Turkish writers' theses, significant variations regarding the other three types of source content transformation were found out in the theses carried out by two groups of writers. First of all, critical evaluation belonged to the third rank as a way of transformation in English L1 writers' theses whereas it was on the last rank in Turkish writers' theses. It can be 


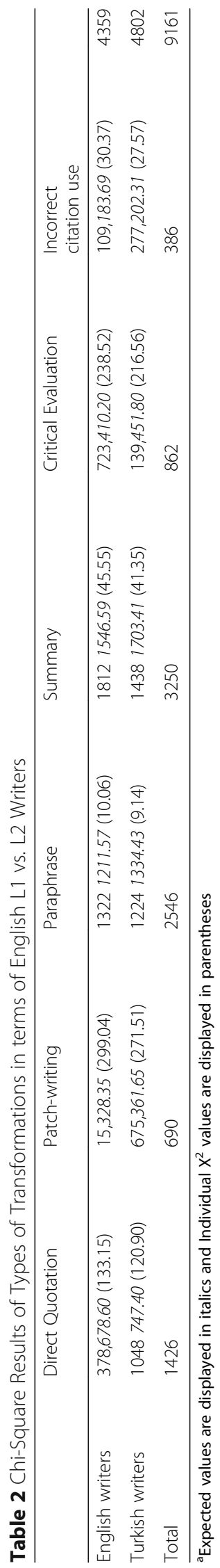


Table 3 The Distribution of Citations in Analysed M.A. and PhD Theses in regard to Type of Transformation

\begin{tabular}{|c|c|c|c|c|c|c|}
\hline \multicolumn{4}{|l|}{ M.A Theses } & \multicolumn{3}{|c|}{ PhD Theses } \\
\hline Type of Transformations & $\mathrm{F}$ & $\%$ & $\begin{array}{l}\text { The order of } \\
\text { preference }\end{array}$ & $\bar{F}$ & $\%$ & $\begin{array}{l}\text { The order } \\
\text { of preference }\end{array}$ \\
\hline Direct Quotation & 704 & 19.0 & 3 & 723 & 13.2 & 3 \\
\hline Patchwriting & 376 & 10.2 & 4 & 314 & 5.7 & 5 \\
\hline Paraphrase & 1051 & 28.4 & 2 & 1495 & 27,4 & 2 \\
\hline Summary & 1116 & 30.2 & 1 & 2134 & 39.1 & 1 \\
\hline Critical Evaluation & 262 & 7.1 & 5 & 600 & 11.0 & 4 \\
\hline Total & 3509 & 94.9 & & 5266 & 96.4 & \\
\hline Incorrect Citation Use & 118 & 5.1 & & 198 & 3.6 & \\
\hline Total & 3697 & 5.11 & & 5464 & & \\
\hline
\end{tabular}

${ }^{a}=$ Frequency, $\%=$ Percentage

${ }^{\mathrm{a}}(1=$ most preferred....5 = least preferred $)$

said that Turkish writers' theses seem to lack necessary critical evaluation in the process of citing. The results of the present study are in accordance with the research findings of Kafes (2017), Yağız et al. (2014), and Candarlı (2012) highlighting lack of critical evaluation in the articles written by Turkish writers. The findings of these studies signal the fact that NNSs of English apparently fail to enact criticality in their scholarly academic papers, which can be attributed to different factors such as cultural factors, lack of academic literacy awareness, insufficient instruction related to citation practices and limited linguistic skills.

Turkish writers appear to draw back from adopting a critical stance in their M.A. and $\mathrm{PhD}$ theses, which can stem from different reasons such as cultural factors, limited linguistic competence and from a consideration of having a critical stance in a scholarly academic work as a face threatening act. This is pertinent but not exclusive to Turkish writers but as other researchers put forward (Borg 2000; Bruce 2014; Lee et al. 2018; Wette 2010), it has become a gradually increasing problem particularly for non-native speakers of English. The avoidance of taking a critical stance in academic work has become a gradually increasing problem for non-native speakers of English as the failure to do so is likely to lead to unintentional plagiarism and interfere with the development of academic integrity on the part of novice writers in the tertiary academic settings (Marsh and Campion 2018). The issue of criticality is crucial in academic writing contexts and laying an emphasis on critical evaluation, in fact, fosters academic integrity. In line with Thompson (2005), it is of great importance for writers to inject their own voice in their academic writing as well as stating their stance regarding other writers' work by positioning their own views in relation to those of others by juxtaposing an array of diverse perspectives. They need to use citations effectively to support their findings as well as construct their knowledge claims. Writers are expected to present their arguments and create links between sources employing a variety of citation strategies.

As for the other two ways of transformation of source content, direct quotation (8.7\% of total citations) was was not preferred as a means of source content transformation in the theses written by English L1 writers while it (21.8\% of citations) was found to be 


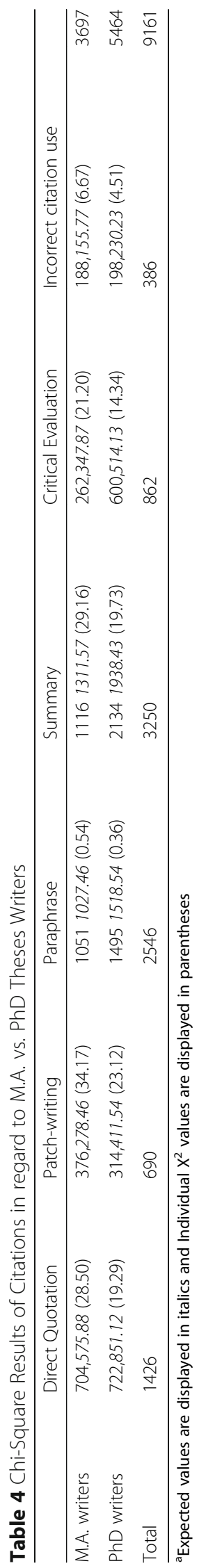


a favourable one in Turkish writers' theses. As can be seen, Turkish writers relied on direct quotation almost three times more than English writers. The results are in line with Yağız et al. (2014). The findings also reveal a difference in the frequency of direct quotation use in M.A. and PhD theses. In PhD theses there is a decrease in the use of this strategy, as compared to M.A. theses. It could be concluded that the differences in citation use is atttibuted to the disciplinary conventions. It may be remarked that as direct quotation is considered a relatively undemanding and simple way of the source content transformation that does not require any textual modifications, it may be preferred by Turkish novice writers in the study who may be relatively unfamiliar with the discipline-specific academic writing conventions and may not feel competent in terms of employing relatively sophisticated citation types such as critical evaluation (Borg 2000; Lee et al. 2018; Wette 2010). According to Petric (2012), more successful learners relied on direct quotation than less successful learners even though in the social sciences less successful L2 students are more prone to make use of direct quotation more frequently in their writings and she sees the overuse of direct quotation as a developmental stage that is necessary for acquiring academic literacy. As the previous academic integrity-related literature suggests, the employment of citations display variation in different disciplines (Bahadorfar \& Gholami, 2017).

As to patchwriting as a way of source content transformation, English L1 writers avoided the use of patchwriting, being the least preferred citation type among other types of transformation of source content, as much as possible in their M.A. and $\mathrm{PhD}$ theses, accounting for $0.3 \%$ of total citations. Nevertheless, Turkish writers made use of patchwriting as the fourth common way of transformation of source content, accounting for $14.1 \%$ of total citations. Patchwriting practices may be attributed to poor paraphrasing skills (Howard 1993). However, most of the researchers (Howard 1993; Pecorari 2003; Wette 2010) claim that patchwriting should be considered a developmental stage rather than deliberate dishonesty but a part of complex development. This finding supports the relevant argument regarding NNS of English writers' making use of patchwriting more commonly in their theses, which seems to stem not only from their developmental needs but also from the challenges of having the full control of a demanding academic literacy.

\section{Conclusion}

The present study primarily aimed to shed light on the similarities and differences between English and Turkish L1 writers in terms of source use. The findings provided a broad view of both groups of writers' (Turkish and English L1 writers) tendencies regarding the ways the cited materials are incorporated into the original text. However, given that the findings reflect the citation practices pertinent to a specific corpus used in the study, it is hard to make broad generalizations concerning the findings. Although summary and paraphrase are the most preferred transformation ways of source content in the theses conducted by Turkish and English L1 writers, there is a greater distinction in the use of direct quotation, patchwriting and critical evaluation between the two sets of theses. Turkish writers' theses have a larger number of direct quotation and patchwriting, which have been found as a more widespread practice in MA and $\mathrm{PhD}$ theses. They also seem to lack critical evaluation. Three forms of content integration (direct quotation, patchwriting and 
critical evaluation) are found to be markedly different in English L1 and Turkish writers' theses. Turkish L1 writers' overuse of direct quotation and patchwriting, and their inclination towards the avoidance of critical evaluation in the process of using other sources appear to arise from their insufficient awareness of conventions and norms of citation practice, insufficient explicit instruction, cultural factors, and linguistic background. In line with the findings, the following suggestions might be made. A new academic integrity approach needs to be established where the faculty staff, students and the institution have a role in assisting students to comprehend the academic integrity expectations at university and how to meet them as well as in raising the student awareness towards the values of academic scholarship and the acquisition of the key competencies related to academic integrity (Marsh and Campion 2018). All the parties are likely to benefit from the development of proper practices for teaching and learning academic integrity and from assuming a responsibility for the enactment and communication of an academic integrity approach to the advantage of all the stakeholders (East and Donnelly 2012).

The findings might act as an awareness-raising agent towards different citation transformation practices adopted by the native and non-native writers, enabling them to ameliorate their academic writing style and elevate the quality of their academic writing. Academicians might consider integrating different citation transformation practices employed in different disciplines such as social and hard sciences into Academic Writing and Research Skills and English for Academic Purposes (EAP) courses in the undergraduate and graduate programs, to raise the awareness of undergraduate as well as graduate students towards citation transformation practices and the textual borrowing issue, thereby enhancing the quality of their existing academic writing practices and paving the way to raise prospective academicians equipped with well-developed advanced writing skills. For course developers, the findings might provide a road map as to how to integrate citation transformation practices in an academic writing and research skills course, which is likely to contribute to the prevention of plagiarism. Further research studies are needed in different contexts to gain further insights into the citation practices of novice and expert writers in different educational settings. To illustrate, citation practices of writers with different academic titles could be investigated. Another research strand for future researchers could be the longitudinal investigation of the trajectory of changes in the citation practices of the writers in the course of their undergraduate and graduate studies. The comparative multi-disciplinary investigation of citation practices across different levels of academic programs might also be recommended. The studies comparing the citation practices among undergraduate and post-graduate level students in social and hard sciences might be a further source of investigation. Also, the impact of academic advisors on the post-graduate students' process of knowledge claim construction and their citation practices could be considered a further area of research.

In conclusion, if we are to raise the standards of academic integrity in the academic settings internationally, we need to establish a collegial atmosphere formed by an awareness of diverse academic writing conventions, including citation practices, across disciplines not only through effective academic instruction but also through institutional collaboration where every stakeholder shares a responsibility in maintaining the standards. 
The investigation of citation practices at different levels of post-graduate education in the Turkish context is likely to benefit the academic writing instructors as well as teacher educators in different ways. It may provide a road map and valuable insights for English as an Academic English (EAP) course developers, academic writing instructors and materials developers in the Turkish context, as well as in similar EFL academic contexts, as to the identification of citation practices post-graduate students, future academics, employ at different points of their academic career, the difficulties they tend to have regarding the appropriate citation use. It may also be beneficial for post-graduate students by familiarizing them with various rhetorical functions in their academic work ranging from the acknowledgement of other scholars' contributions to the evaluation of arguments, and by raising their awareness of the impact these various functions on academic writing. Hence, the study findings are also likely to enhance the academic integrity of EFL/ESL post-graduate students by honing their citation skills. They are also likely to be useful for the aforementioned audience in addressing the concerns arising from the lack of familarity with discipline-specific academic writing conventions and citation styles in order to enhance the post-graduate students' level of academic integrity, which, in return, contributes to academic integrity in the Turkish tertiary academic context as well as similar EFL academic writing contexts elsewhere.

\title{
Additional file
}

Additional file 1: Appendix A. The Rubric Employed in Textual Analysis. (DOCX 26 kb)

\begin{abstract}
Abbreviations
EAP: English for Academic Purposes; ELT: English Language Teaching; EThOS: Electronic Theses Online Service; L1: Native language; L2: Foreign Language; M.A.: Master of Arts; NNS: Non-native speakers of English; PhD: Doctor of Philosophy; TESOL: Teaching English to Speakers of Other Languages; UK: United Kingdom; YÖK: The Council of Higher
\end{abstract} Education in Turkey

\begin{abstract}
Acknowledgments
This study has been extracted from the first author's PhD thesis under the supervision of the second and the third authors in 2016. I would like to thank my advisors who inspired me about the theoretical framework, the research procedure, and for proofreading the final version of the study.

Publication costs (APC) for this article have been supported thanks an educational grant from Studiosity Pty Ltd. The article was independently prepared by the authors and has undergone peer review in accordance with the journal's standard policies and processes. Studiosity Pty Ltd. had no input into the topics covered or the article itself.
\end{abstract}

Funding

This research received the grant from TUBITAK (The Scientific and Technological Research Council of Turkey) under the program of 2211 (Graduate Scholarship Programme) during the process of first author's PhD journey.

\section{Availability of data and materials}

The confidentiality of the data has been preserved and the data have not been shared with any party. The theses analyzed in this research were all open access.

\footnotetext{
Undertaking

The authors confirm that that the content of the manuscript has not been published, or submitted for publication elsewhere. Yet, the paper was orally presented in "Plagiarism across Europe and Beyond", 9th-11th May 2018.
}

Authors' contributions

FŞD carried out the study and analyzed the texts in terms of citations and drafted the manuscript. Before the main study OY and IGK determined the criteria for the theses selection to analyze. OY and IGK participated in the design of the rubric for the analysis. OY and IGK participated in the deciding about the type of citations when needed. FŞD performed the statisctical analysis. All authors read and approved the final manuscript. 


\section{Publisher's Note}

Springer Nature remains neutral with regard to jurisdictional claims in published maps and institutional affiliations.

\section{Author details}

${ }^{1}$ Harran University, Şanlıurfa, Turkey. ${ }^{2}$ Atatürk University, Erzurum, Turkey. ${ }^{3}$ Middle East Technical University, Ankara, Turkey.

Received: 2 July 2018 Accepted: 26 September 2018

Published online: 03 November 2018

\section{References}

Al-Shamaa S, Brown A, Pranish T (2017) Addressing plagiarism at a New Zealand tertiary institute. ATLAANZ J 2(2):16-32 Retreived from http://journal.atlaanz.org/index.php/ATLAANZ/article/view/36/64

Angelil-Carter S (2000) Stolen language? Plagiarism in writing. Pearson Education, Essex

Bahadorfar R, Gholami J (2017) Types and functions of citations in master's theses across disciplines and languages. Discourse and Interaction. 10:27-45. https://doi.org/10.5817/DI2017-2-27

Borg E (2000) Citation practices in academic writing. In: Thompson P (ed) Patterns and perspectives: Insights into EAP writing practice. the University of Reading, Reading, pp 27-45

Bruce I (2014) Expressing criticality in the literature review in research article introduction in applied linguistics and psychology. Engl Specif Purp 38:85-96 https://doi.org/10.1016/j.esp.2014.06.004

Burns RB (1991) Study and stress among first year overseas teachers in an Australian university. High Educ Res Dev 10(1):6777 https://doi.org/10.1080/0729436910100106

Campbell C (1998) Teaching second language writing: interacting with text. Heinle \& Heinle, Boston

Candarlı D (2012) A cross-cultural investigation of English and Turkish research article abstracts in educational sciences, Studies about Language, pp 12-20 http://dx.doi.org/10.5755/j01.sal.0.20.1770

Coffin C (2009) Incorporating and evaluating voices in a film studies thesis. Writ Pedag 1:163-193. https://doi.org/10.1558/ wap.v1i2.163

Davidse K, Vandelanotte L (2011) Tense use in direct and indirect speech in English. J Pragmat 43:236-250 https://doi.org/10. 1016/j.pragma.2010.07.022

East J (2009) Aligning policy and practice: an approach to integrating academic integrity. J Acad Lang Learn 3(1):A38-A51 http://journal.aall.org.au/index.php/jall/article/viewArticle/66. Accessed 18 Aug 2018

East J, Donnelly L (2012) Taking responsibility for academic integrity: a collaborative teaching and learning design. J Univ Teach Learn Pract 9(3):1-11 https://ro.uow.edu.au/cgi/viewcontent.cgi?referer=https://scholar.google.com.tr/\&httpsredir= 1 \&article $=1354 \&$ context=jutlp. Accessed 20 Aug 2018

Emerson L (2008) Plagiarism, a Turnitin trial and an experience of cultural disorientation. In: Eisner C, Vicinus M (eds) Originality, imitation, and plagiarsim: teaching writing in the digital age. University of Michigan, University of Michigan Press, pp 183-194

Handa N, Power C (2005) Land and discover! A case study investigating the cultural context of plagiarism. J Univ Teach Learn Pract 2(3):64-84 https://ro.uow.edu.au/cgi/viewcontent.cgi?article=1035\&context=jutlp. Accessed 1 Sep 2018

Harwood N (2009) An interview-based study of the functions of citations in academic writing across two disciplines. J Pragmat 41:497-518 https://doi.org/10.1016/j.pragma.2008.06.001

Hinkel E (2002) Second language writers' text. Lawrence Erlbaum, Mahwah

Howard RM (1993) A plagiarism pentimento. J Teach Writ 11:233-246 https://eric.ed.gov/?id=EJ475663. Accessed 31 Oct 2014

Howard RM, Serviss T, Rodrigue TK (2010) Writing from sources, writing from sentences. Equinox Publishing 2(2):177-192

Hyland K (1999) Academic attribution: citation and the construction of disciplinary knowledge. Appl Linguis 20:341-367 https://doi.org/10.1093/applin/20.3.341

Hyland K (2000) Disciplinary discourses: social interactions in academic writing. Longman, London

Hyland K (2002) Activity and evaluation: reporting practices in academic writing. In: Flowerdew J (ed) Academic discourse. Longman, London, pp 115-130

Işık-Taş EE (2008) A corpus-based analysis of genre-specific discourse of research: The research article and the PhD thesis in ELT. Dissertation, Middle East Technical University, Ankara

Jalilifar A, Dabbi R (2013) Citation in applied linguistics: analysis of introduction sections of Iranian master's theses. Linguistik online 57(7):91-104. https://doi.org/10.13092/lo.57.252

Kafes H (2017) Citation practices among novice and expert academic writers. Educ Sci 42:441-462. https://doi.org/10.15390/ EB.2017.6317

Lee JJ, Hitchcock C, Casal JE (2018) Citation practices of L2 university students in first-year writing: form, function and stance. J Engl Acad Purp 33:1-11 https://doi.org/10.1016/j.jeap.2018.01.001

Mansourizadeh K, Ahmad UK (2011) Citation practices among non-native expert and novice scientific writers. J Engl Acad Purp 10:152-161 https://doi.org/10.1016/j.jeap.2011.03.004

Marsh JD, Campion J (2018) Academic integrity and referencing: whose responsibility is it? J Acad Lang Learn 12(1):213-226 Mohan BA, Lo WAY (1985) Academic writing and Chinese students: transfer and developmental factors. TESOL Q 19(3):515534. https://doi.org/10.2307/3586276

Pecorari D (2003) Good and original: plagiarism and patchwriting in academic second language writing. J Second Lang Writ 12:317-345 https://doi.org/10.1016/j.jslw.2003.08.004

Pennycook A (1996) Borrowing others' words: text, ownership, memory and plagiarism. TESOL Q 30(2):201-230. https://doi. org/10.2307/3588141

Petric B (2007) Rhetorical functions of citations in high- and low-rated master's theses. J Engl Acad Purp 6:238-253 https:// doi.org/10.1016/j.jeap.2007.09.002

Petric B (2012) Legitimate textual borrowing: direct quotation in L2 student writing. J Second Lang Writ 21(2):102-117 https://doi.org/10.1016/j.jslw.2012.03.005 
Schembri N (2009) Citation practices: insights from interviews with six undergraduate students at the University of Malta. Language Studies Working Papers 1:16-24. https://pdfs.semanticscholar.org/7edc/ d91cae0c491827ab9fbc620a8a48858d29d5.pdf

Swales J (1986) Citation analysis and discourse analysis. Appl Linguis 7:39-56 https://doi.org/10.1093/applin/7.1.39

Swales J (1990) Genre analysis: English in academic and research settings. Cambridge University Press, Cambridge

Thompson G, Ye Y (1991) Evaluation in the reporting verbs used in academic papers. Appl Linguis 12(4):365-382 https://doi. org/10.1093/applin/12.4.365

Thompson P (2005) Points of focus and position: intertextual reference in PhD theses. J Engl Acad Purp 4(4):307-323 https:// doi.org/10.1016/j.jeap.2005.07.006

Wette R (2010) Evaluating student learning in a university-level EAP unit on writing using sources. J Second Lang Writ 19(3): 158-177. https://doi.org/10.1016/j.jslw.2010.06.002

Yağız O, Ötügen R, Kaya F, Aydın B (2014) A literature review analysis of the Turkish scholars' research articles in ELT and applied linguistics. In: 14th international language, literature and stylistics symposium, 15-17 October 2014. Procediasocial and behavioral sciences, vol 158, pp 389-393 https://doi.org/10.1016/j.sbspro.2014.12.105

Ready to submit your research? Choose BMC and benefit from:

- fast, convenient online submission

- thorough peer review by experienced researchers in your field

- rapid publication on acceptance

- support for research data, including large and complex data types

- gold Open Access which fosters wider collaboration and increased citations

- maximum visibility for your research: over 100M website views per year

At BMC, research is always in progress.

Learn more biomedcentral.com/submissions 